\title{
Historein
}

Vol 16, No 1-2 (2017)

Greek Historiography in the 20th Century: Opening a Research Agenda

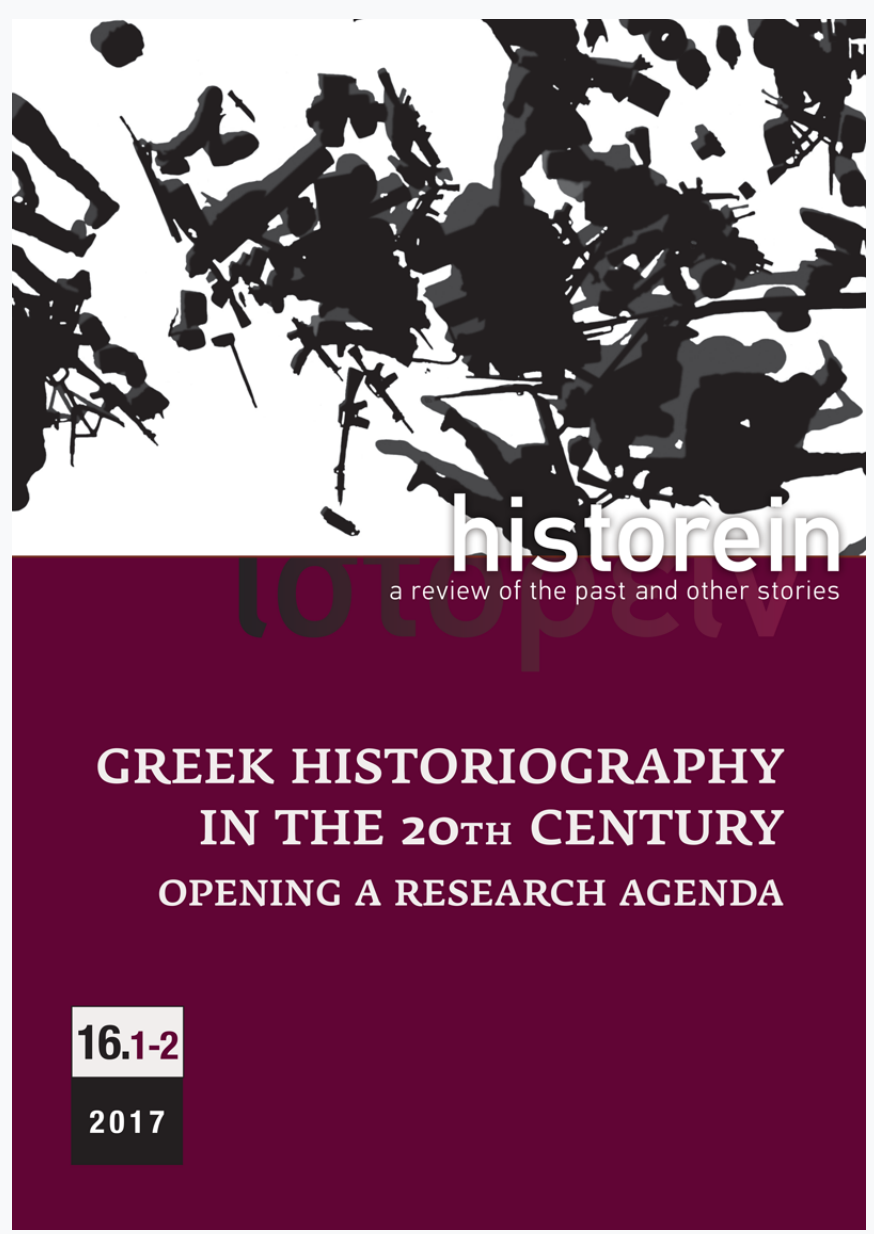

\section{Historisising twentieth-century historiography}

Antonis Liakos

doi: $\underline{10.12681 / \text { historein.10030 }}$

Copyright @ 2017, Antonis Liakos

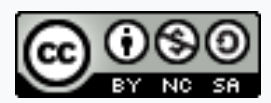

This work is licensed under a Creative Commons Attribution-NonCommercialShareAlike 4.0.

To cite this article:

Liakos, A. (2017). Historisising twentieth-century historiography. Historein, 16(1-2), 139-148. https://doi.org/10.12681/historein.10030 


\section{DIALOGOS}

What profile did historiography enjoy in the twentieth century? European historiography in the nineteenth century has been well documented, due to the pioneering work of Georg Iggers, but also of Stefan Berger, Daniel Woolf and others.' But before asking this question, is it possible to talk about a concrete or coherent profile of historiography in the last century? And does historiography follow the periodisation implied by the sequence of centuries? What has been the experience of historians? People who entered the historiographical field around the 1970s and who since then have been monitoring the repeated turns and multiple directions of historiography are inclined to see a discontinuity between the era of their experience and the previous decades. Woolf, in his multivolume history of world historiography, describes the first part of the twentieth century as a sequel of nineteenth-century historiography, and starts the chapter on contemporary history in the postwar period. But some of the main issues that arose in the last part of twentieth century had already emerged in its first part. The theory of history, in both its forms, as a turn to social sciences (Max Weber and Fustel de Coulanges) and to hermeneutics (Benedetto Croce and R. G. Collingwood), is an early example of this enduring concern in the twentieth century about the status of history. ${ }^{2}$ The philosophy of history - and its main exponents Martin Heidegger, Hans-Georg Gadamer and the Frankfurt School - cannot be excluded from this deep interest in "historicality". ${ }^{3}$ The turn also to social anthropology was not only a product of the 1970s. The fathers of social anthropology were engaged in a dialogue on the deep structures of history since the publication of James Frazer's The Golden Bough in $1894 .^{4}$

\section{Historising}

twentieth-century

\section{historiography}

\section{Antonis Liakos}

University of Athens 
The historiography of the twentieth century has been often described as a tower of Babel (Woolf), as a multitude of groups going in different directions and unable to agree, even on what history is and what historians are supposed to do (Chris Lorenz), and as anarchy (Peter Novick, concluding his book on the American historical profession, declared that "there is no king in Jerusalem"). 5 Even references to sexual promiscuity were not missing from the metaphors. History in the nineteenth century was the queen of the disciplines; now she was a harlot, searching casual relationships each night with new disciplines.

"Babel" means the multiplication of languages, and the impossibility to communicate, as God's punishment. Indeed, history at the end of the twentieth century was deeply specialised, with each group using its own jargon. Miscommunication among historians was guaranteed. But in order to understand the linguistic confusion of historiography, we need a code, and the question is where to search for it: inside or outside the history of historiography?

Historiography is not something unrelated to the society that produces it. Since the nineteenth century, historians have actively participated in the building of modern nation-states and societies. Historians bear the imprint of the culture in which they are formed, their research is used in the education system, their writings address wider audiences and they participate in the public sphere. They often participate as experts in domestic or foreign affairs, in intergovernmental conferences or in dealing with international problems. Historians are sometimes honoured, others are persecuted, while some of the most influential historical works have been written in prison or in exile. ${ }^{6}$ As the consequence of those thoughts, the main hypothesis of this conference ${ }^{7}$ is that cracking the polyglossia of historiography consists in understanding how historiography responds to historical challenges and in exploring the nexus between these challenges and historiography.

Does history exist outside historiography? This is an intriguing question, at the heart of many of the fierce quarrels at the end of the last century regarding the distinction between the past and its relationship to historiography. But despite the many ways to narrate twentieth-century history, there is agreement on its main trends. The majority of historians in liberal democracies no longer use the image of a linear history unfolding towards progress, or of history passing through laws, from one stage to the other. Contingency is something they have already learned, without describing the history of the twentieth century as a chaotic series of events, as we do, regarding historiography.

Often, the twentieth century is described as a dark century of wars, holocausts, death and pain. This is true, but it is only a partial image of the century. Mass killing was an essential but partial feature of this century. Below, I propose discussing five major challenges and their relations to historiography:

1 The disintegration of empires, decolonisation and the rise of new nations

2 The impact of world wars (genocides, revolutions, totalitarian regimes)

3 The boom in technoscience and the digital era

4 The ascent of rights, the transformation of gender relations and mass literacy

5 Globalisation 
These changes were experienced by, broadly, three generations of historians. The first generation appeared before the First World War. The second generation was active from the end of that war to the 1960s and 1970s, and the third since the last quarter of the twentieth century.

Has the history of historiography responded to these challenges or does it also have an internal logic? And how has it responded? This is the question that this article raises.

\section{The disintegration of empires, decolonisation and the rise of new nations}

The disintegration of the European empires and the longer process of decolonisation resulted in the proliferation of nation-states and of national historical communities. Even the nations without a state, or the ethnic minorities aspiring to nationhood, choose history as a camp in which to forge their identities and aspirations. This blossoming of nations resulted in a multiplication of historical communities, and a worldwide explosion in the number of historians. But can we talk about the expansion or transplantation of historiography? Historiography was adopted to, but also adapted in, various national cultures and political regimes. For example, while historiography in Greece was created in the nineteenth century with a rather complex relationship with the state, in Turkey it was created in the twentieth century as a national project, under the direct supervision of the founding father of the Turkish republic, Mustafa Kemal Atatürk. While Greek national historiography emerged in a romantic environment, the Turkish one was bore the traces of French positivist sociology. Another example is the impact of German historiography in Scandinavian countries. While social history was a minor trend in German historicism, nevertheless it had a major impact on Finnish and Swedish historiography. The history of national historiographies is a history of communication and adaptation. Historiography, having been adopted by the new nation-states, acquired a global dimension, substituting older forms of historical writing (mainly in China and Japan, where a long, imperial historical tradition expired at the beginning of twentieth century). In colonial countries, the writing of history was introduced by the colonisers, and the history of the colonies was related to the history of colonisation. During the era of decolonisation, independent states created their own historiographies, using a mixture of nationalist and Marxist idioms. Nevertheless, the decisive factor was the linguistic belonging to the British, French and Hispanic spheres of influence, and the interaction of historians writing in the same language and sharing the same tradition. ${ }^{8}$ Anticolonial and postcolonial histories represent different moments of historiography, but each linguistic continent also shares common historiographical trends with its metropolis.

The multiplication of historians and historical communities around the world could be seen as a wave moving between homogenisation of the form and differentiation of the content. History was sailing in two boats: one was traveling in national bays, the other in international waters. The first addressed the national audience while claiming an international reputation; the second addressed an international audience but on behalf of the national self.

During the twentieth century, the nationalisation of history proceeded hand in hand with the internalisation of history-writing through international conferences, international historical reviews and the 
formation of historical schools. The contrasting images of the international congresses of history, between the first conferences at the beginning of the century in Paris, Rome and Berlin and the international conferences in Toronto and Sydney a century later, give a good sense of the historiographical transformations in the intervening period. ${ }^{9}$ At the beginning of the century, the congresses were attended by a few middle-aged European male historians, from well-to-do backgrounds. At the end of the century, thousands of men and women, many of them young and from Asia, Latin America and Africa, attended the historical congresses. The composition of the corpus of historians has also had an impact on the orientations of historiography. Then, it was political and diplomatic history of Europe which hegemonised historiography. Now, it is mostly the history of the world outside Europe, involving cultural, gender, environmental and dozens of new themes and specialisations, that attracts the bigger audiences at international historical hubs. The international conferences were organised every five years at the beginning of the century; now there are a great number every year that are very well attended. The Atlas of European Historiography, by llaria Porciani and Lutz Raphael, demonstrates the spectacular transformation of the historical profession, the increasing number of historical societies, the historical institutions, archives and museums in Europe, and the changing relationship between genders in history. ${ }^{10}$ And this expansion was not only European or North American. New history departments, historical magazines and historical societies have emerged since the 1960s, following the multiplication of universities and the increase in student numbers.

How has this expansion changed historiography? Is it obvious that specialisation multiplied with the number of languages, and national spaces have resulted in a great variety of historical methods, works and theories - to an extent that is not comparable with other social sciences - which also expanded during this century. Nevertheless, the English- and French-speaking worlds acquired the leading role in forming paradigms of historical thinking with worldwide impact, replacing the older German tradition.

\section{The impact of world wars (genocides, revolutions, totalitarian regimes)}

War was the godfather of historical writing. Both Herodotus and Thucydides wrote histories of wars. But the impact of the two great wars of the twentieth century was greater than the writing of the history of these wars. It pushed history into deep waters and off course. Both wars set in motion three big changes in historical thinking and its relation with the past. First, they undermined the belief in progress, which had inspired most of nineteenth-century historiography and cemented the belief in history. In the aftermath of the First World War, Oswald Spengler wrote The Decline of the West and Arnold J. Toynbee, a decade later, A Study in History, demonstrating the rise and the fall of civilisations. ${ }^{11}$ The second big change was the emergence of memory as a public culture. War monuments and the cult of the dead soldier were established everywhere in Europe, and ever since have afforded history the role of a guardian of memory. During the same period the theories of collective or social memory (Maurice Halbwachs) began to emerge. ${ }^{12}$ The third event that would change the relationship between history and the past was Sigmund Freud's concept of trauma. This theory emerged from the medical experience in the trenches, but spread to psychoanalysis, and from there to the way we realise our relations to the wounds in the collective memory of the 
past..$^{13}$ After the First World War, we no longer faced the past alone before us. Historians began to take an interest in the past within us, in our relation to it. History was no more out there; history took its place inside the mind of the people, posing a challenge for historians.

The Second World War had overwhelming and long-lasting consequences for historiography. While the First World War was also a historians' war, involving exacerbating nationalism and the use of history as weapon of war (the only predictive exception were the writings of Henri Pirenne, who, as a Belgian prisoner of war in Germany, sought to denationalise the concepts used by history), after the Second World War, nation and historiography were no longer an unexamined condition of writing history. Although the writing of national histories in a patriotic spirit lingered on, after the experience of war the criticism and the re-examination of the relationship between nationalism and historiography began to spread rapidly and to have an impact on international organisations. History writing and teaching was connected to the preservation of peace. Unesco started the publication of a new kind of world history, and in the conferences on historical education, international standards prevailed over the national. Ever since, nationalism has been one of the central topics in historiography and social science. Starting from Hannah Arendt, George Mosse, Hans Kohn and others in the 1950s, this strand culminated in the 1980s with topics regarding the imagined communities, the invention of tradition and the construction of the nation and the national self, which had a tremendous impact on the way of writing national history. ${ }^{14}$

The criticism of the relationship between nation and history not only affected the explicit criticism of nationalism. Its impact was bigger in overturning the pre-Second World War historical paradigms. Not one of the prewar historical schools remained untouched after the war. Germany saw the debates on the Sonderweg, France the prevalence of the Annales school over republican history, and Britain the rise of social history and the almost complete disappearance of Whig historiography. All these overturnings were signs of the new direction in historical writing. But the war also opened another future path.

The mass extermination of whole populations during the war, mainly the European Jews, highlighted the problem of genocide as a legal and political problem. The research on the Holocaust did not commence immediately after the war. But it had long-lasting consequences in the new way of dealing with memory, and most of all in the way of dealing with trauma. Trauma, a Freudian concept, was passed to history, together with a group of new concepts from psychoanalysis. Writing trauma, and writing about trauma, opened new epistemological perspectives in history. ${ }^{15}$

The United Nations convention on the prevention and punishment of genocide in 1948 opened a vast space in thinking about the past. In the following years, the expansion of the definition of what constitutes a "genocide" and the drive for recognition of cases of genocide would lead to an effort by various nations or ethnic groups to seek revenge for past injustices. The term "genocide", as a sign of recognition of the crimes committed, was used in order to validate in public memory the suffering of a community, and to produce a demand for respect. Categorised as genocides, past sufferings acquire the status of a distinct criminal action, whose history becomes a moral source for preventing similar atrocities in the future. This moral dimension also affected historical thinking. By institutionalising the memory of crimes against humanity, the world order after the Second 
World War established a certain way of remembering some moments of the past and proclaimed them as a moral value that needed to be respected, even by memory laws. I think that we should view historiography within these aspects, which gave it a mass dimension, but also a political aspect, mainly in societies emerging from colonialism, where crimes, similar to that of the European wars, were committed.

It is still difficult to understand the dimensions of the legacy of the two world wars on the intellectual and emotional life of European societies, and on the way they use this toolbox of experiences, examples and concepts drawn from the wars for thinking their present past and present.

\section{The boom in technoscience and the digital era}

The twentieth century was not only a century of mass annihilation. It was also the century of the laboratory, the century of Albert Einstein, Niels Bohr, Henri Poincaré and Werner Heisenberg, as well the century of the internet and the transition from print capitalism to the digital age. Was historiography untouched by this technoscientific challenge? How did historiography respond to the new era that was surrounded by an aura of utopia and futurology? How did historians respond to the relativity of time and the principle of uncertainty? It is true that historians did not abandon the Newtonian conception of time and the literary style of nineteenth-century realism. Were there exceptions? Henry Adams, visiting the World Exposition in Paris in 1900, wrote an essay entitled "The Dynamo and the Virgin", advocating a dynamic theory of history that would track and forecast the use of energy by advanced societies. But few historians heeded him. The response to the challenge of relativity came from Claude Lévi-Strauss, who proposed the elaboration of a theory of civilisations going beyond linear history and the hierarchy of civilisations, to a plurality and relativity of cultural forms and structures. For Novick, social anthropology was the missing response of historians to the theory of relativity. ${ }^{16}$ Indeed, historians have learned from anthropologists how to proceed in exploring different societies, and even more on how to see the historical past through anthropological lenses. This was an enduring love affair that flourished in the second part of the twentieth century.

Another aspect of the new cultural environment, which was created in the new world of laboratories and scientific communities, was the dehumanisation of history, and the breakup of the cause-effect chain. Historians turned their attention from the histories in which human intentionality starred, to more humble but observable and measurable facts, like prices, demographic data and so on. At the same time temporality became more complex. Time was relevant to space, to vast geographical areas, to mentalities and experiences. Causality became more complex and new methods of analysis were introduced, borrowed from the social sciences. The impact of science created a new discipline, the history of science, and through it a new paradigm and language to describe the history of science emerged, encapsulated in the theories of Thomas Kuhn. ${ }^{17}$

But the response of historiography to the galloping changes in societies under the impact of technoscience did not go hand-in-hand towards the future. It turned in the opposite direction. History was used as a counterbalance to the insecurities and the anxieties of the future. The elegy for the 
past was an antidote for the hymns of the future. The regressive view became more visible in the final decades of the twentieth century, coming from different provenances. When E. P. Thompson declared his intention to save the poor "stockinger, the Luddite cropper, the 'obsolete' hand-loom weaver ... from the enormous condescension of posterity", no one was expecting a mass movement of social history that would turn the past into a repository of alternative values and possibilities. ${ }^{18}$ This was a general cultural trend. In the second part of the twentieth century, both the future and the past changed positions. The memory boom, the turn to heritage, the emphasis on the pastness of the past, microstoria, the new historical novel, the affluence of historical films and the mass proliferation of museums have transformed the past into a cult object. In a rapidly changing world, history was used as a way to recapture what was lost. The concept of loss became a cover for the disposition of historical studies. The turn of historians' attention from events to experiences can be explained by this wish to reappropriate what has been lost.

Finally, the digital era, the online book and new technology also introduced history to the new era with still unexplored consequences. What does the passing of the past from its material representation to its virtual reality mean? In the era of the manuscript, the few wrote for the few; in the era of print, the few wrote for the many, but in the virtual era, many are writing for the many. The style of writing has also changed. Online texts are complex units with windows to other references, while the use of video, music and other tools have dramatically changed the linear, two-dimensional way we expose our thoughts.

\section{The ascent of rights, the transformation of gender relations and mass literacy}

How can the theoretical interest in history since the 1970 s be explained? This question is crucial to understanding the history of twentieth-century historiography. It is true that the theoretical debate on history did not disappear over the course of the century. But what was new in the final decades of the century was the shift from the epistemology of history to the poetics of history, and from the question of how our knowledge of the past could be reliable, to the question of how we represent history. A new terminology promising radical turns appeared in the historical debates. This era of instability and reorientations is well documented in Geoff Eley's intellectual autobiography A Crooked Line. ${ }^{19}$ The question is why did these intense debates and changes in historiography happen? A common explanation is that they correspond to the end of certainties and the grand narratives of modernity. But this explanation recycles the question without offering a response.

Since this reorientation in history followed a big way of criticism, of campus protests and unrest during the late 1960s and late 1970s, and since most of the bearers of these intellectual shifts were active in these movements, is it possible to establish a link between historical changes and changes in history?

I'm referring to the civil rights movements and the anti-Vietnam War movements in the US, to the '68 generation in eastern Europe, to the transition-to-democracy cultures in the Mediterranean, to 
the Prague Spring and the democratisation movements in eastern Europe, to the feminist movements around the world, to queer theories, to anticolonial revolutions, to the cultural left in the west. This kaleidoscopic world, despite its many differences, has formed the world of historians who begun their university studies in the 1970s. In this broad movement, human rights formed an integral and fundamental part to the extent that it is hardly possible to imagine a world without the idea, practices, relationships and morality associated with them. Instead of placing the state at the centre of historical thinking, the broader intellectual result of the human rights movement was the emergence of a new sensitivity for individuals and society as sovereign subjects. The silent consensus around the human rights ideology that was formed cut across ideological differences and built bridges in the understanding of the different realities of the non-European and non-western worlds. The consequences of this change of mentalities was the liberation of historiography from the intellectual bondages of the state, but also the liberation of the past from the teleology of modernity and the judgement of posterity. The rise of feminism, both as a civil rights movement and as an epistemological shift to gender studies in the academy, put history and historiography under criticism and helped reconsider the fundamental premises of history. From this point of view, Joan Scott's criticism, and the shift from feminist history to gender history, re-examined the basic intellectual concepts and prerequisites of the writing of history. ${ }^{20}$

This turn has questioned the status of meaning and was accompanied by new terms and new ways of dealing with inequalities and differences. Identity and subjectivity, gender, class and race, culture, experience and linguistic construction, discourse and discursive practices, contingency and numerous other neologisms have changed the style of historical writing. Language was no longer a tool to understand reality but became part of the reality.

\section{Globalisation}

For a discipline interweaved with the nation-state, globalisation was a major challenge. But older than the writing of national histories was the writing of universal histories, and since the nineteenth century, the interest in world history has existed side by side with national histories. The novelty of global historiography was to explore how the world changed in interconnection, how new changes cut across countries and continents and to see the world beyond the canon and the periodisation of western historiography.

Since the works by William McNeill and Leften Stavrianos, both based in the US, global historiography took various forms. The American education system places considerable emphasis on the rise of the value of western civilisation. Modernisation theories have also produced similar histories of big changes, mainly in the field of the political and social sciences. Another strong tendency was realised by the neo-Marxist schools. One is the school of world-systems theory (Immanuel Wallerstein and Giovanni Arrighi, historical sociology with Charles Tilly, Theda Skocpol and Saskia Sassen); the other, the dependency theory school (Paul A. Baran, Paul Sweezy, Andre Gunder Frank and others) during the 1970s and 1980s. Eric Hobsbawm was another very influential figure in this field. 
Although the 1990s witnessed an increasing interest in global history, the terms global and transnational history were disseminated during the first decades of the present first century.

But the challenge of globalisation was more decisive than the changes in the content of global history. Historians began circulating internationally, most of them trying to serve two masters and to address two, quite different audiences: a national one, in their own language, and an international one, in the shared language of English. Due to the dense international communication, a new koine language of historiography emerged, which is still under construction. This language is beyond the control of historians. History for the broad audiences has been reforged in the language of the media and in the priorities of international cultural politics. Here, Google, Amazon and other giga-portals are the main players. In contrast, defensive national communities of history have also emerged, often in clear distinction to the professional communities of historians. These communities defend and popularise their own national or local history, in terms of safeguarding a besieged past. Most of the history wars in recent years took place in this field. These debates expanded into cultural wars around the status of the past in the present while historiography was connected to transitional justice in many countries emerging from dictatorships and civil wars. Consequently, history has acquired a new public role and new dimensions. At the same time, the first histories of global historiography also appeared. These global approaches have changed the perspectives of many historians on subjects related even to national history.

Concluding this bird's-eye view on of twentieth-century historiography, it was my intention to test some hypotheses on the relationship between history and historiography in this century, regarding five major changes in political, social and cultural history. I hope that this will kick start some discussions at the conference.

\section{NOTES}

1 Georg lggers, Historiography in the twentieth century: from scientific objectivity to the postmodern challenge (Hanover: University Press of New England, 1997); Axel Schneider and Daniel Woolf, eds., The Oxford history of historical writing. Vol 5, Historical writing since 1945 (Oxford: Oxford University Press, 2011). And also Stefan Berger et al., eds., Writing the nation: national historiographies and the making of nation states in 19th- and 20th-century Europe (Basingstoke: Palgrave Macmillan, 2008).

2 Max Weber, General economic history (New York: Greenberg, 1927), and idem, The Protestant Ethic and the Spirit of Capitalism (London: Unwin Hyman, 1930); Fustel de Coulanges, The ancient city: a study on the religion, laws and institutions of Greece and Rome (Boston: Lee \& Shepard, 1877); Benedetto Croce, Teoria e storia della storiografia (Bari: Gius. Laterza \& Figli, 1920), and idem, La storia come pensiero e come azione (Bari: Laterza, 1938); R. G. Collingwood, The idea of history (New York: Oxford University Press, 1946).

3 Martin Heidegger, Being and time (New York: Harper \& Row, 1962, originally published in German, in 1927); Hans-Georg Gadamer, Wahrheit und Methode (Tübingen: Mohr, 1960), and idem, "Hermeneutics and Social Science," Cultural Hermeneutics (now Philosophy Social Criticism) 2 (1975): 307-16.

4 James Frazer, The golden bough: a study in comparative religion (New York: Macmillan, 1894).

5 Daniel Woolf, A global history of history (Cambridge: Cambridge University Press, 2011); Chris Lorenz, 
"History and theory," in The Oxford history of historical writing. Vol 5, Historical writing since 1945, ed. Axel Schneider and Daniel Woolf (Oxford: Oxford University Press, 2011); Peter Novick, That noble dream: the "objectivity question" and the American historical profession (Cambridge: Cambridge University Press, 2007).

6 "Writing history in exile." Special issue, Storia della Storiografia 69/1 (2016).

7 History of twentieth-century historiography, Athens, 18-20 Jun. 2015.

8 Robert Young, Postcolonialism: an historical introduction (Oxford: Blackwell, 2001).

9 Karl Dietrich Erdmann, Toward a global community of historians: the international historical congresses and the International Committee of Historical Sciences, 1898-2000 (New York: Berghahn, 2005).

10 Ilaria Porciani and Lutz Raphael, eds., Atlas of European historiography: the making of a profession (Basingstoke: Palgrave Macmillan, 2010).

11 Oswald Spengler, The decline of the west, vol. 1 (New York: Macmillan, 1922) and vol. 2 (London: Allen and Unwin, 1922); Arnold Toynbee, A study of history, 14 vols (Oxford: Oxford University Press, 1934-61).

12 Maurice Halbwachs, "Les cadres sociaux de la mémoire," in Les travaux de l'année sociologique (Paris: F. Alcan, 1925); Stefan Berger and Bill Niven, Writing the history of memory (London: Bloomsbury, 2014).

13 Stefanos Geroulanos and Todd Meyers, The brittleness of the body and the sciences of the individual around World War I (forthcoming).

14 Hannah Arendt, The origins of totalitarianism (New York: Harcourt, Brace and Co, 1951); George Mosse, The culture of western Europe: the nineteenth and twentieth centuries; an introduction (Chicago: Rand McNally, 1961); Hans Kohn, Nationalism: its meaning and history (Princeton: Van Nostrand, 1955).

15 Michael Roper, "Psychoanalysis and the making of history," in The Sage handbook of historical theory, ed. Nancy Pertner and Sarah Foot (London: Sage, 2013), 311-25; George Makari, Revolution in mind: the creation of psychoanalysis (New York: HarperCollins, 2008).

16 Claude Lévi-Strauss, Race et histoire (Paris: Unesco, 1952); Novick, That noble dream, 143-45.

17 Thomas Kuhn, The structure of scientific revolutions (Chicago: University of Chicago Press, 1962).

18 E. P. Thompson, The making of the English working class (London: Victor Gollancz, 1963).

19 Geoff Eley, A crooked line: from cultural history to the history of society (Ann Arbor: Michigan University Press, 2008).

20 Joan Scott, "Gender: a useful category of historical analysis," American Historical Review 91/5 (1986): 1053-75. 